\title{
Productivity and economic efficiency of growing of fruit of an apple in different constructions of a garden on clonal stocks
}

\author{
V. Zhuk, \\ Cand Agr Sci \\ L. Barabash, \\ Cand Ec Sci \\ Institute of Horticulture, NAAS of Ukraine
}

The purpose. To develop the most effective constructions of a garden for bogharic conditions of Boreal Forest-steppe of Ukraine. Methods. Field, design and calculative. Results. Features of formation of productivity of trees and productivity of plantations of an apple in different constructions of a garden on clonal stocks are studied. The best constructions based on indexes of economic efficiency are chosen. Conclusions. To heighten efficiency of growing fruits of an apple in bogharic conditions is possible at building high density constructions of a garden of separate cultivars on medium-height stock $54-118$. That allows ensuring the level of profitableness up to $150-177,8 \%$.

Key words: cultivars of an apple, intense techniques, constructions of plantations, growing energy, productivity of trees, productivity of plantations, economic efficiency.

The modern technologies of apple fruits growing are based on the all-round intensification. As a complex of techniques and methods of increasing the production and manufacturing processes efficiency the intensification, has a certain aim: reducing the investments payback period owing to the earlier beginning of the orchards fruitbearing; achieving the maximum production efficiency level on the basis of the standardization of the potential high of the orchards productivity; provision of the fruitbearing stability through applying the complex of innovative components; ensuring the low production costs due to high yield; enlarging the fruit bearing resource for the entire period of the agrocoenosis exploitation etc. [1].

It is the trellis-dwarf orchard that as the most early-ripening one meets to the greatest degree the demands of the apple fruits growing intensification in the word and in Ukraine.

However, these orchards are extraorrdinarily capital-intensive. The need for the significant investments to create them is conditioned first of all by increasing the thickness of planting trees, by rising of the planting stock cost as well as of logistical means for the implementation of the appropriate processes [2-6].

In connection with the considerable capital intensity of the above mentioned orchards the actual problem is increase of the apple fruits production efficiency. It can be achieved by introducing technologies aimed at the reduction of the orchards capital intensity while their creating. The basis of such technologies can be high-dense orchards without supports and of the basis of such orchards intensive cultivars on rootstocks with the average growth energy. The mutual influence of such varieties and rootstocks stipulates the trees growth energy under which in different soil and climatic conditions the optimization of planting plans and formation of the trees crowns is necessary to obtain such a structure of the overall trees biological productivity in which the share of fruits would provide the highest yield of plantations. At the same time these orchards must not be more energy intenscive, but more convenient and economically more adwantageous than trellis-dwarf ones.

The purpose of the researches was development of the most efficient orchards constructions for the conditions with irrigation in the Northern part of the Lisosteppe.

Methods. The researches were conducted at the Institute of Horticulture (NAAS of Ukraine), where an experiment had been established in the spring of 2007 in which the varieties Radohost' and Skif ske Zoloto were evaluated in the orchard constructions on the dwarf rootstocks M.9, 62-396 and D-10-71 with 
a planting plan of $4 \times 0.8-1.0 \mathrm{~m}$; semidwarf M.26 and those with the average growth energy - 54-118 and $57-490(4 \times 1.0-1.5 \mathrm{~m})$. The columnform $(4 \times 0.8 \mathrm{~m})$, spindle-like (graceful spindle $(4 \times 1 \mathrm{~m})$ and orbicular one-story $(4 \times 1.5 \mathrm{~m})$ crowns were formed depending on the planting thickness. As a control, were the trees on the rootstock M.9 $(4 \times 1 \mathrm{~m})$ and with the formation of the graceful spindle were used as a control. The repetition was three-fold. The number of registration trees in a repetition was four. The soil on the experimental area was dark gray podzolized with agrochemical indicators specific for this type.

We used conventional methods of carrying out field experiments [7]. The economic efficiency of various orchards constructions was determined in accordance with "Methods of the economic evaluation of the plantations types cultivars, capital investment, innovations and results of the technological researches in horticulture" [8]. The calculations conducted on the basis of flow sheets and methodical recommendations according to the standard allowances and price lists which were valid in the agricultural enterprises of the Northern part of the Ukraine's Lisosteppe.

Results. In the experiment the sizes of the eight-year trees crowns of both cultivars in different orchards constructions depended on a rootstock. In particular, on the dwarf rootstock M.9, D-10-71 on 62396 the crowns height was 2.2-2.4 $\mathrm{m}$ and volume 2.9-4.5 $\mathrm{m}^{3}$. On the rootstock M.26 (semidwarf), these indices rose on the average by $4.1-13.6$ and $15.5-62.0 \%$ and on those with the average growth energy (54-118 and $57-490)$ - by $14.5-33.3$ and $82.8-153.3 \%$ respectively.

In intense plantations of any construction the entire volume of crowns must be evenly filled with productive wood and level of leaf surface high enough for the formation of fruiting structures and high quality fruits lighting on it.

The optimum leaf surface in the full-aged orchard is considered to be $20-25$ thousand $\mathrm{m}^{2} /$ ha, while for the formation of stabily high yield of high quality fruits this indicator is to be by 1.6-2.0 times higher [4-7]. In the conditions of the experiment during the full fruit-bearing period dwarf plantations with different thickness of planting trees provided a leaf surface of 15.8-24.7 thousand $\mathrm{m}^{2}$, semidwarf ones $-12.0-22.5$ thousand $\mathrm{m}^{2}$ and those with the average growth energy - 18.8- 42.5 thousand $\mathrm{m}^{2} / 1$ ha. The index of the leaf productivity (yield per $1 \mathrm{~m}^{2}$ of the leaf surface per one tree) in the above mentioned plots was 1.1 $3.6 ; 1.3-3.6$ and $0.7-2.9 \mathrm{~kg} / \mathrm{m}^{2}$ respectively. Trees with much lower growth energy on dwarf and semidwarf rootstocks distinguished themselves according to this indicator. At the same time the stands construction of the cultivar Radohost on the rootstock 54-118 and 57-490 with a planting thickness of 2,500 trees/ha and formation of the spindle-like crown provided to the best degree the leaf surface that is necessary for the potentially high yields (table. 1).

Table 1. Growth energy and fruit-bearing of apple cultivars on vegetative rootstocks in the orchard planted in 2007 depending on its construction

\begin{tabular}{|c|c|c|c|c|c|}
\hline \multirow{2}{*}{$\begin{array}{l}\text { Rootst } \\
\text { ok }\end{array}$} & \multirow{2}{*}{$\begin{array}{c}\text { Plantin } \\
\text { g plan, } m\end{array}$} & \multicolumn{2}{|c|}{ Radohost } & \multicolumn{2}{|c|}{ Skifs ke Zoloto } \\
\hline & & $\begin{array}{l}\text { trunk } \\
\text { sectional area } \\
\text { in } 2014, \mathrm{~cm}^{2}\end{array}$ & $\begin{array}{c}\text { yield in 2012- } \\
2014 \text { per } 1 \mathrm{~cm}^{2} \text { of } \\
\text { the cross } \\
\text { sectional area, kg }\end{array}$ & $\begin{array}{c}\text { trunk } \\
\text { cross- } \\
\text { sectional area } \\
\text { in } 2014, \mathrm{~cm}^{2}\end{array}$ & $\begin{array}{c}\text { yield in } 2012- \\
2014 \text { per } 1 \mathrm{~cm}^{2} \text { of } \\
\text { the cross- } \\
\text { sectional area, kg }\end{array}$ \\
\hline \multirow[t]{2}{*}{ M. 9} & $4 \times 1,0$ & 10,7 & 1,15 & 19,60 & 0,89 \\
\hline & $4 \times 0,8$ & 9,10 & 0,90 & 13,20 & 0,98 \\
\hline \multirow{2}{*}{$\begin{array}{l}\text { D-10- } \\
71\end{array}$} & $4 \times 1,0$ & 12,00 & 0,82 & 12,60 & 1,18 \\
\hline & $4 \times 0,8$ & 11,90 & 0,87 & 11,90 & 1,53 \\
\hline \multirow[t]{2}{*}{$62-396$} & $4 \times 1,0$ & 15,90 & 0,74 & 22,10 & 0,98 \\
\hline & $4 \times 0,8$ & 13,20 & 0,92 & 15,20 & 1,22 \\
\hline \multirow[t]{2}{*}{ M. 26} & $4 \times 1,5$ & 24,60 & 0,70 & 22,10 & 1,03 \\
\hline & $4 \times 1,0$ & 18,10 & 0,94 & 16,60 & 1,24 \\
\hline \multirow[t]{2}{*}{$54-118$} & $4 \times 1,5$ & 52,10 & 0,55 & 40,70 & 0,92 \\
\hline & $4 \times 1,0$ & 45,10 & 0,67 & 37,40 & 0,62 \\
\hline \multirow[t]{2}{*}{$57-490$} & $4 \times 1,5$ & 50,80 & 0,30 & 50,20 & 0,65 \\
\hline & $4 \times 1,0$ & 43,00 & 0,35 & 40,70 & 0,50 \\
\hline
\end{tabular}

The trunk cross sectional area is a universal index that reflects the growth energy and potential of the trees overall biological productivity in different orchard constructions. Its structure depends on the nature 
of the leaf photosynthesis products redistribution. The peculiarity of the latter reflects to the best degree the index of the growth productivity (fruit weight $(\mathrm{kg})$ on conversion to $1 \mathrm{~cm}^{2}$ of the trunk cross-sectional area) $[9,10,11,12]$. The eight-year trees of cvs Radohost' and Skifs'ke Zoloto on the dwarf rootstocks

M. 9, D 10-71 and 62-396 in different orchard constructions had the average value of this indicator within 9.1-22.1 and on the semidwarf one M. 26 as well as on 54-118 and 57-490 (with the average growth energy) it increased to $16.6-24.6$ and $37.4-52.1 \mathrm{~cm}^{2}$. At the same time the index of the growth productivity of the trees on the dwarf rootstocks in different orchards constructions was $0.74-1.18$, on the semidwarf one $0.70-1.24$ and on those with the average growth energy it decreased to $0.30-0.92 \mathrm{~kg} / \mathrm{cm}^{2}$ (table 1 ).

Thus the low growth energy of the trees on semidwarf and dwarf rootstocks ensured the best redistribution of the photosynthesis products of the formation of the economic crop, their growth energy on the rootstock 54-118 and especially 57-490 - much more skeletal and crowns of the total number of entities and fruit harvest fruit in them.

The above mentioned peculiarity concerning the growth energy and trees productivity provided the average yield of the orchard structures of the both varieties on the dwarf rootstocks for the first five years after the beginning of the fruit-bearing within 16.3-35.1, on the semidwarf one - 16.1-28.4, and on those with the average growing energy - 12.8-35.6 t/ha. As for this indicator the 'Radohost potential was realized to the best degree in the stands on the rootstock 54-118 with the average growing energy while placing about 2500 trees per 1 ha and shaping the crown in the form of the graceful spindle ( $35.6 \mathrm{t} / \mathrm{ha}$ ). Concerning cv Skif'ske Zoloto the maximum yield was ensured in the plots on 62-396 with a thickness of planting to 3125 trees per 1 ha while shaping the column from crown (35.1 t / ha) and on 54-118 when placing 1,666 trees per 1 ha and maintaining the crown in the form of the orbicular one story $(34.2 \mathrm{t} / \mathrm{ha})$ (tables 2, 3).

For the production conditions the informations become important about how economically justified the application of certain elements of the cultivation technology is, what additional financial costs are necessary for it and whether they provide achieving the appropriate income and profitability.

In order to compare any orchard constructions and to determine the most effective ones in addition to the data about the yield that can be achieved due to different expenses of resources a comprehensive economic evaluation is needed that includes the accounting of costs and labor during the period of creation and productive use of plantations [13].

Orchards on dwarf and semidwarf rootstocks need applying the support-trellis structure, which increases significantly the cost of their creation, that together with other factors effects the efficiency. In our researches the investments for the creation of such orchards were 2500 trees - 249.3 thousand grn. per 1 ha, 3125 trees - 286.6 and 1666 trees - 199.5 thousand grn. per 1 ha depending on the planting thickness $23.3-25.8 \%$ of them for the support-trellis constructions. In the production costs for the maintenance of a fertile orchard the amortization for the recovery of the trellis cost was $7.5-8.5 \%$.

In the trellis-dwarf plantations in the treatment with the highest yield $(35.1 \mathrm{t} / \mathrm{ha})$ the production cost of $1 \mathrm{t}$ of fruits was 2.3 thousand grn., income per 1 ha -94.8 thousand grn., profitability level $-117.4 \%$, investment payback period -6 years.

In the high-dense orchards constructions without supports the investments for creating which were 148.1-189.2 thousand grn. per 1 ha together with high yield the highest indicators of the economic efficiency were noted. In the plantations on the rootstock 54-118 with a thickness of 1666 trees per 1 ha (the cultivar Skif'ske Zoloto) and 2,500 trees per 1 ha grade ('Radohost') the production cost of $1 \mathrm{t}$ of fruits was 1.8 and 2.0 thousand grn. respectively, income per 1 ha - 109.4 and 106.8 thousand grn., profitability level -177.8 and $150.0 \%$, the investment payback period -4.4 and 4.8 years respectively. 
Table 2. Economic efficiency growing the of fruits of the apple cultivar Radohost depending on the orchard construction on vegetative rootstocks with different growing energy (average for 2010-2014)

\begin{tabular}{|c|c|c|c|c|c|c|c|c|c|c|c|c|}
\hline \multirow{2}{*}{ Indices } & \multicolumn{2}{|c|}{ M. 9} & \multicolumn{2}{|c|}{ D-10-71 } & \multicolumn{2}{|c|}{$62-396$} & \multicolumn{2}{|c|}{ M. 26} & \multicolumn{2}{|c|}{$54-118$} & \multicolumn{2}{|c|}{$57-490$} \\
\hline & $4 \times 1$ (c.) & $4 \times 0,8$ & $4 \times 1$ & $4 \times 0,8$ & $4 \times 1$ & $4 \times 0,8$ & $4 \times 1,5$ & $4 \times 1$ & $4 \times 1,5$ & $4 \times 1$ & $4 \times 1,5$ & $4 \times 1$ \\
\hline Yield, $\mathrm{t} / \mathrm{ha}$ & 22,6 & 20,5 & 16,3 & 20,3 & 19,6 & 25,3 & 16,1 & 26,4 & 23,9 & 35,6 & 12,8 & 18,4 \\
\hline Production costs per 1 ha, thousand grn. & 62 & 66,2 & 58,8 & 66,1 & 60,5 & 68,6 & 51,8 & 63,9 & 51,4 & 63,5 & 45,9 & 54,9 \\
\hline $\begin{array}{l}\text { including the amortization for the support } \\
\text { trellis structure: } \\
\text { thousand grn. }\end{array}$ & 5,0 & 5,5 & 5,0 & 5,5 & 5,0 & 5,5 & 4,3 & 5,0 & - & - & - & - \\
\hline specific weight, \% & 8,1 & 8,3 & 8,5 & 8,3 & 8,3 & 8,0 & 8,3 & 7,8 & - & - & - & - \\
\hline $\begin{array}{l}\text { Production cost of } 1 \mathrm{t} \text { of the realized } \\
\text { products, thousand grn. }\end{array}$ & 3,0 & 3,6 & 4,0 & 3,6 & 3,4 & 3,0 & 3,5 & 2,7 & 2,4 & 2,0 & 3,9 & 3,3 \\
\hline Products realization value, thousand grn. & 113,0 & 102,5 & 81,5 & 101,5 & 98,0 & 126,5 & 80,5 & 132,0 & 119,5 & 178,0 & 64,0 & 92,0 \\
\hline Profit per 1 ha, thousand grn. & 45,2 & 28,7 & 16,3 & 28,4 & 31,4 & 50,6 & 24,2 & 60,7 & 62,1 & 106,8 & 14,1 & 31,3 \\
\hline Profitablness level, \% & 66,7 & 38,9 & 25,0 & 38,9 & 47,1 & 66,7 & 42,9 & 85,2 & 108,3 & 150,0 & 28,2 & 51,5 \\
\hline $\begin{array}{l}\text { Investments for the creation of } 1 \text { ha of } \\
\text { plantations, thousand. UAH. }\end{array}$ & 249,3 & 286,6 & 249,3 & 286,6 & 249,3 & 286,6 & 199,5 & 249,3 & 148,1 & 189,2 & 148,1 & 189,2 \\
\hline $\begin{array}{l}\text { including the install support-trellis } \\
\text { constructions, thousand grn. }\end{array}$ & 60,1 & 66,7 & 60,1 & 66,7 & 60,1 & 66,7 & 51,4 & 60,1 & - & - & - & - \\
\hline Specific weight, \% & 24,1 & 23,3 & 24,1 & 23,3 & 24,1 & 23,3 & 25,8 & 24,1 & - & - & - & - \\
\hline Years of the plantations establishment & 3,0 & 3,0 & 3,0 & 3,0 & 3,0 & 3,0 & 3,0 & 3,0 & 3,0 & 3,0 & 4,0 & 4,0 \\
\hline Term of the investment payback, years & 8,5 & 13,0 & 18,3 & 13,1 & 10,9 & 8,7 & 11,3 & 7,1 & 5,4 & 4,8 & 14,5 & 10,0 \\
\hline
\end{tabular}


Table 3. Economic efficiency of growing the fruits of the apple cultivar Skifs'ke Zoloto orchard construction on vegetative rootstocks with different growing energy (average for 2010-2014)

\begin{tabular}{|c|c|c|c|c|c|c|c|c|c|c|c|c|}
\hline \multirow{2}{*}{ Indices } & \multicolumn{2}{|c|}{ M. 9} & \multicolumn{2}{|c|}{ D-10-71 } & \multicolumn{2}{|c|}{$62-396$} & \multicolumn{2}{|c|}{ M. 26} & \multicolumn{2}{|c|}{$54-118$} & \multicolumn{2}{|c|}{$57-490$} \\
\hline & $4 \times 1(\kappa)$ & $4 \times 0,8$ & $4 \times 1$ & $4 \times 0,8$ & $4 \times 1$ & $4 \times 0,8$ & $4 \times 1,5$ & $4 \times 1$ & $4 \times 1,5$ & $4 \times 1$ & $4 \times 1,5$ & $4 \times 1$ \\
\hline Yield, t / ha & 23,7 & 25,2 & 23,1 & 33,6 & 31,4 & 35,1 & 21,2 & 28,4 & 34,2 & 32,4 & 26,9 & 23,3 \\
\hline Production costs per 1 ha, thousand grn. & 62,5 & 68,5 & 62,2 & 72,7 & 66,4 & 73,4 & 54,3 & 64,9 & 56,5 & 61,9 & 52,9 & 57,3 \\
\hline $\begin{array}{l}\text { including the amortization for the support- } \\
\text { trellis construction: } \\
\text { thousand grn. }\end{array}$ & 5,0 & 5,5 & 5,0 & 5,5 & 5,0 & 5,5 & 4,3 & 5 & - & - & - & - \\
\hline specific weight, \% & 8,0 & 8,0 & 8,0 & 7,6 & 7,5 & 7,5 & 7,9 & 7,7 & - & - & - & - \\
\hline $\begin{array}{l}\text { The production cost of } 1 \mathrm{t} \text { the realized } \\
\text { products, thousand grn. }\end{array}$ & 2,9 & 3 & 3 & 2,4 & 2,3 & 2,3 & 2,8 & 2,5 & 1,8 & 2,1 & 2,2 & 2,7 \\
\hline Products realization value, thousand grn. & 118,5 & 126,0 & 115,5 & 168,0 & 157,0 & 175,5 & 106,0 & 142,0 & 171,0 & 162,0 & 134,5 & 116,5 \\
\hline Profit per 1 ha, thousand grn. & 49,8 & 50,4 & 46,2 & 87,4 & 84,8 & 94,8 & 46,6 & 71,0 & 109,4 & 94,0 & 75,3 & 53,6 \\
\hline Profitableness level, $\%$ & 72,4 & 66,7 & 66,7 & 108,3 & 117,4 & 117,4 & 78,6 & 100,0 & 177,8 & 138,1 & 127,3 & 85,2 \\
\hline $\begin{array}{l}\text { Investments for the creation of } 1 \text { ha } \\
\text { plantations, thousand. UAH. }\end{array}$ & 249,3 & 286,6 & 249,3 & 286,6 & 249,3 & 286,6 & 199,5 & 249,3 & 148,1 & 189,2 & 148,1 & 189,2 \\
\hline $\begin{array}{l}\text { including the installment of the support- } \\
\text { trellis: thousand grn. }\end{array}$ & 60,1 & 66,7 & 60,1 & 66,7 & 60,1 & 66,7 & 51,4 & 60,1 & - & - & - & - \\
\hline Specific weight, \% & 24,1 & 23,3 & 24,1 & 23,3 & 24,1 & 23,3 & 25,8 & 24,1 & - & - & - & - \\
\hline Years of the plantations establishment & 3,0 & 3,0 & 3,0 & 3,0 & 3,0 & 3,0 & 3,0 & 3,0 & 3,0 & 3,0 & 4,0 & 4,0 \\
\hline Term of the investment payback, years & 8,0 & 8,7 & 8,4 & 6,3 & 5,9 & 6,0 & 7,3 & 6,5 & 4,4 & 5,0 & 6,0 & 7,5 \\
\hline
\end{tabular}




\section{Conclusions}

Apple trellis-dwarf orchards distinguish themselves for early ripening and high yield, but at the same time they are relatively high capital intensive. Increasing the production efficiency, reducing the costs for the establishment of this crop stands is possible owing to the introduction of innovative methods of resource-saving, foreseeing the creation of high dence orchards of certain cultivars without supports on rootstocks with the average growing energy. Under the conditions without irrigation such orchards provide the highest profitability level (150-177.8\%).

\section{References}

1. Yegorov Y.A. Ekonomicheskaya sushchnost' riesursosbyeryezhyeniya $v$ intensivnom plodovodstvye / Y.A. Yegorov, Zh.A. Shadrina, G.A. Kosyan // Sadovodstvo i vinogradarstvo. - 2014.- 5. - S. 7-12.

2. Mika Augustyn Sad karlowy /Augustyn Mika // Hortpress Sp. z.o.o. - 2000. - $276 \mathrm{~s}$.

3. Makosh Eberhard. Pol'skoie sadovodstvo s ekonomichieskoi tochki zrieniia / Eberhard Makosh. Liublin : Progonosfruit, 2004. - $71 \mathrm{~s}$.

4. Eccher T. Fruit quality and yield of different apple cultivars as affected by tree density / T. Eccher, G. Granelli // Acta Horticulturae: Proceedings of the IVth International Conference on Managing Quality in Chains MQUIC, 2006, Integrated View on Fruits and Vegetables Quality, Volume 1, Bangkok, Thailand, August 7-10. - 2006. - P. 535-540.

5. Klemsova Z. Intensive orchards in the Czech republic / Z. Klemsova // Acta Horticulturae: International Conference of Perspectives in European Fruit Growing, Lednice, Czech Republic, October 18-20, 2006. - P. 11-12.

6. Hricovsky I. Development of fruit planting in the Slovak republic after its accession to the European Union / I. Hricovsky, H. Vargova // Acta Horticulturae: International Conference of Perspectives in European Fruit Growing, Lednice, Czech Republic, October 18-20, 2006. - P. 13-15.

7. Kondratenko P.V. Metodyka provedennia poliovych doslidzhen z plodovymy kulturamy I P.V. Kondratenko, M.O. Bublyk. - K. : Agrarna nauka, 1996. - $96 \mathrm{s.}$

8. Metodyka ekonomichnoi energetychnoi otsinky typiv nasadzhen', sortiv, investytsii $v$ osnovnyi kapital, innovatsii ta rezul'tativ technolohichnych doslidzhen` u sadivnytstvi / Za redaktsiieiu O.M. Shestopalia. - K. : IS UAAN, 2006. - $140 \mathrm{~s}$.

9. Kudriaviets R.P. Produktivnost` iabloni / R.P. Kudriaviets - M. : Agropromizdat, 1987. - $303 \mathrm{~s}$.

10. Potapov V.A. Slaborosliy intensivnyi sad / V.A. Potapov,

A.S. Ilianishchiev, Yu.V. Krysanov i dr. - M. : Rosagropromizdat, 1991. - 221s.

11. Gul'ko I.P. Klonovi pidshchepy iabluni / I.P. Gul'ko. - K.: Urozhai, 1992. - 155 s.

12. Lieonovich I.S. Otsenka biologychieskich i ekonomichieskich osobiennostiei vozdielyvaniia ustoichivych k parshie sortov iabloni v Riespublikie Bielarus / I. S. Lieonovich, T.M. Kostiuchienko // Plodovodstvo. T.20. - 2008. - S. 115-117.

13. Barabash L.O. Mietodichieskie aspiekty ekonomichieskoi otsenki raznych konstruktsii intensivnych plodovych nasazhdienii / L.O. Barabash, V.N. Zhuk // Plodovodstvo: nauch. tr. Samochvalovichi, 2006. - T.18, ch.2. - S. 252-256. 